\title{
Talampicillin and probenecid compared with ampicillin and probenecid for the treatment of gonococcal urethritis in men
}

\author{
S. Al-EGAily,* E. M. C. DUNlop,* P. RODIn,* AND A. D. SETH† \\ From the *Whitechapel Clinic, and the †Venereal Diseases Reference Laboratory, \\ The London Hospital, London E1
}

SUMMARY Two hundred and ten men suffering from uncomplicated gonococcal urethritis were treated with one of two treatment schedules. Of 109 patients treated with $3 \mathrm{~g}$ ampicillin and $2 \mathrm{~g}$ probenecid (group A) there were two recurrences in the first week after treatment and none in the second week. Of 101 patients treated with $1.5 \mathrm{~g}$ talampicillin and $2 \mathrm{~g}$ probenecid (group B), there were three recurrences in the first week and none in the second week. Both antibiotics were well tolerated, but one patient vomited two hours after taking talampicillin. The sensitivity pattern of Neisseria gonorrhoeae to penicillin at The London Hospital has shown an increase in the proportion of more sensitive strains during the last three years. Talampicillin given in a single dose with probenecid is satisfactory in the treatment of acute gonococcal urethritis but, apart from the smaller dosage, it does not offer any advantage over ampicillin with probenecid.

\section{Introduction}

Talampicillin is a thiazolidine carboxylic ester of ampicillin which releases ampicillin after hydrolysis in the gut mucosa to produce concentrations in the blood up to twice as high as those achieved with ampicillin. Urine levels are also greater. Its absorption is affected by food to a lesser extent, and it has less effect on the faecal flora than ampicillin (Leigh et al., 1976).

Willcox (1976) treated 81 patients for gonococcal urethritis with a single oral dose of $1.5 \mathrm{~g}$ talampicillin, without probenecid, and reported a failure rate of only $4.2 \%$ among those seen at least once after treatment; it was without side effects. He concluded that talampicillin was the most potent ampicillin-like antibiotic so far available for the treatment of gonorrhoea and a smaller single dose was capable of curing the disease than would have been needed with ampicillin.

Price et al. (1977) treated 245 patients suffering from uncomplicated gonorrhoea with $1.48 \mathrm{~g}$ talampicillin and $1 \mathrm{~g}$ probenecid and reported a failure rate of only $1.6 \%$ in patients seen at least once after treatment.

Address for reprints: S. Al-Egaily, The Whitechapel Clinic, The London Hospital, Turner Street, London E1

Received for publication 21 February 1978
Men presenting at The London Hospital with uncomplicated gonorrhoea are usually treated with a single oral dose of $3 \mathrm{~g}$ ampicillin and $2 \mathrm{~g}$ probenecid. It was decided to compare the result of this treatment (Group A) with that of talampicillin and probenecid (Group B) and to study the sensitivity pattern of Neisseria gonorrhoeae to penicillin to see if there had been any change since the report by Taylor and Seth (1975).

Men suffering from uncomplicated gonococcal urethritis were chosen for the trial.

As talampicillin gives peak serum ampicillin concentrations that are about twice as high as those with the same dose of ampicillin the results of treatment with $1.5 \mathrm{~g}$ talampicillin and $2 \mathrm{~g}$ probenecid (Group B) were compared with the results of treatment with $3 \mathrm{~g}$ ampicillin and $2 \mathrm{~g}$ probenecid (Group A).

\section{Material and methods}

Two hundred and ten men suffering from acute gonococcal urethritis were randomly allocated to one of two single-dose treatment schedules. Any patient who was allergic to penicillin, a habitual defaulter, unable to attend for regular follow-up, homosexual, or was suspected of having syphilis was excluded. Seventeen additional patients whose urethral smears contained classical Gram-negative, 
intracellular diplococci but in whom urethral cultures did not yield gonococci were not included in the analysis.

\section{AGE AND NATIONALITY}

The mean age, age range, and nationalities in the two groups are shown in Table 1.

\section{FOLLOW-UP TESTS}

The patients were advised to attend for follow-up on or about the 3rd, 7th, 14th, and 28th day after treatment. At each visit a smear and a culture were taken from the urethra whether or not there was obvious discharge.

Post-gonococcal urethritis was diagnosed from the eighth day onwards if the leucocyte count per high power field (HPF) with a total magnification of $\times 1000$ was over 30 . These patients were treated with oxytetracycline $500 \mathrm{mg}$ orally four times a day for two weeks.

\section{DEFAULT RATE}

Of the 210 patients in the trial 193 attended at least once after treatment (Table 2).

\section{SENSITIVITY TESTS}

Sensitivities to ampicillin and penicillin were determined by an agar plate dilution method and the minimum inhibitory concentrations (MIC) reported. Brain heart infusion agar (Oxoid) was used for testing the sensitivity. Penicillin and ampicillin were incorporated in the following concentrations: $0.004,0.008,0.015,0.03,0.06$, $0 \cdot 125,0.25$, and $0.5 \mu \mathrm{g} / \mathrm{ml}$. The inoculum consisted of a suspension of gonococci from a 24-hour-old plate subculture suspended in a nutrient broth (Oxoid) to give a turbidity approximately equal to a No. 2 MacFarland barium sulphate standard prepared in a nutrient broth. The plates containing the two antibiotics were inoculated by using a multipoint inoculator (Denley Instruments Ltd) the prongs delivering about $10^{4}$ colony-forming units. The inoculated plates were incubated at $36^{\circ} \mathrm{C}$ in a candle extinction jar for 48 hours before readings were taken.

Staphylococcus aureus (Oxford) and two World Health Organisation $N$. gonorrhoeae reference strains III and V (A. Reyn, Statens Seruminstitut, Kopenhagen) were included as controls on each plate.

\section{Results}

Recurrences in the two groups are shown in Table 3.

\section{GROUP A}

There were eight recurrences. Of these six occurred after the second week of follow-up, and each patient admitted further sexual intercourse with the untreated contact or with a new partner later shown to be infected. It is likely that these six recurrences

Table 1 Age and nationality of patients in each group

\begin{tabular}{|c|c|c|c|c|c|c|}
\hline \multirow[b]{2}{*}{ Group } & \multicolumn{2}{|c|}{ Age (years) } & \multicolumn{3}{|l|}{ Nationality } & \multirow[b]{2}{*}{ Total } \\
\hline & Mean & Range & $U K$ and Eire & Caribbean & Others & \\
\hline $\begin{array}{l}\text { A } \\
\text { B }\end{array}$ & $\begin{array}{l}27 \cdot 8 \\
30 \cdot 2\end{array}$ & $\begin{array}{l}16-47 \\
18-60\end{array}$ & $\begin{array}{l}35 \\
48\end{array}$ & $\begin{array}{l}45 \\
36\end{array}$ & $\begin{array}{l}29 \\
17\end{array}$ & $\begin{array}{l}109 \\
101\end{array}$ \\
\hline
\end{tabular}

Table 2 Duration of follow-up in each group

\begin{tabular}{lllllllll}
\hline & \multicolumn{2}{l}{ Duration of follow-up (weeks) } & & & \\
\cline { 2 - 8 } Group & 0 & 1 & 2 & 3 & 4 & $>4$ & Total \\
\hline A & 14 & 95 & 84 & 56 & 44 & 31 & 109 \\
B & 3 & 98 & 82 & 59 & 45 & 37 & 101 \\
\hline
\end{tabular}

Table 3 Results of treatment

\begin{tabular}{|c|c|c|c|c|c|c|c|}
\hline \multirow[b]{3}{*}{ Group } & \multirow[b]{3}{*}{ No. treated } & \multirow[b]{3}{*}{ No. followed up } & \multicolumn{5}{|c|}{ Recurrences } \\
\hline & & & \multicolumn{2}{|c|}{ First week } & \multirow[b]{2}{*}{ Second week } & \multicolumn{2}{|c|}{$>2$ weeks } \\
\hline & & & No. & $\%$ & & No. & $\%$ \\
\hline $\begin{array}{l}\mathbf{A} \\
\mathbf{B}\end{array}$ & $\begin{array}{l}109 \\
101\end{array}$ & $\begin{array}{l}95 \\
98\end{array}$ & $\begin{array}{l}2 \\
3\end{array}$ & $\begin{array}{l}2 \cdot 1 \\
3 \cdot 1\end{array}$ & $\begin{array}{l}0 \\
0\end{array}$ & $\begin{array}{r}6 \\
10\end{array}$ & $\begin{array}{r}6 \cdot 3 \\
10 \cdot 1\end{array}$ \\
\hline
\end{tabular}


were caused by reinfection. Two patients had recurrences in the first week. One patient admitted sexual intercourse with his untreated infected wife and had an organism sensitivity to $0.008 \mu \mathrm{g} / \mathrm{ml}$ ampicillin before and after treatment; this recurrence could well have been a reinfection. The second patient denied further sexual intercourse when he attended three days after treatment, and he was asymptomatic. Gonococci were not found in the smear, but were grown on culture, so his treatment was considered to have failed. The organism was sensitive to ampicillin $0.015 \mathrm{~kg} / \mathrm{ml}$. Both patients responded to kanamycin $2 \mathrm{~g}$ intramuscularly.

\section{GROUP B}

There were 13 recurrences. Of these 10 occurred after the second week, and the patients admitted further sexual intercourse with the untreated contact or with a new infected partner; these 10 recurrences were thus probably reinfections.

Of the remaining three recurrences, two were in patients who admitted further sexual intercourse with their untreated contacts. In one of these patients the organism was sensitive to $0.03 \mu \mathrm{g} / \mathrm{ml}$ ampicillin. In the other the organism was cultured three days after treatment and was sensitive to $0.03 \mu \mathrm{g} / \mathrm{ml}$ ampicillin. In the third patient, who vomited two hours after swallowing the tablets, the organism was sensitive to $0 \cdot 25 \mu \mathrm{g} / \mathrm{ml}$ ampicillin. This patient denied further sexual intercourse when he attended three days after treatment. The organism isolated after treatment was sensitive to $0.5 \mu \mathrm{g} / \mathrm{ml}$ ampicillin. The recurrence in this patient was considered as a failure of treatment; he responded to spectinomycin $2 \mathrm{~g}$ intramuscularly.

Post-gonococcal urethritis $(P G U)$

The incidence and time of detection are shown in Table 4. Most of the PGU was detected in the second week. The difference in incidence, $30 \%$ and $35 \%$, was not significant $\left(\%^{2}=1 \cdot 094 ; \mathrm{P}=0.3\right)$.

\section{Side effects}

Apart from the patient who vomited two hours after swallowing the talampicillin and probenecid, no other side effects were observed.

\section{RESULTS OF SENSITIVITY TESTS}

The sensitivity of the gonococci to ampicillin and to penicillin was tested in 95 of the patients in group A and in 85 of those in group B (Tables 5 and 6).

The percentage of less sensitive strains to penicillin was a little higher in group A (Table 5), but the groups had virtually identical percentages of less sensitive strains to ampicillin (Table 6). The penicillin and ampicillin sensitivities of the strains of gonococci for those patients who subsequently had recurrences are shown in Table 7.

\section{Discussion}

Talampicillin with probenecid is an effective treatment for gonorrhoea, but in the dose used there was no significant difference in the outcome of treatment in the two groups.

Table 4 Incidence of post-gonococcal urethritis (PGU)

\begin{tabular}{lcccccc}
\hline \multirow{3}{*}{ Group } & & No. assessed & \multicolumn{2}{l}{ Time of detection of $P G U$} & \\
\cline { 3 - 6 } & No. treated & for $P G U$ & Second week & Third week & Fourth week & Total \\
\hline A & 109 & 84 & 18 & 4 & 3 & 25 \\
B & 101 & 82 & 20 & 6 & 3 & 29 \\
\hline
\end{tabular}

Table 5 Penicillin sensitivities in the two groups in $\mu \mathrm{g} / \mathrm{ml}$

\begin{tabular}{lllllllr}
\hline Group & No. tested & 0.06 or less & 0.125 & 0.25 & 0.5 & $>0.5$ & sensitive to 0.125 or nore \\
\hline A & 95 & 71 & 5 & 13 & 5 & 1 & $25 \cdot 3$ \\
B & 85 & 69 & 11 & 3 & 2 & 0 & $18 \cdot 8$ \\
\hline
\end{tabular}

Table 6 Ampicillin sensitivities in the two groups in $\mu \mathrm{g} / \mathrm{ml}$

\begin{tabular}{llllllll}
\hline Group & No. tested & 0.06 or less & 0.125 & 0.25 & 0.5 & $>0.5$ & \% sensitive to 0.125 or more \\
\hline A & 95 & 68 & 16 & 9 & 1 & 1 & 28.4 \\
B & 85 & 61 & 15 & 9 & 0 & 0 & 28.2 \\
\hline
\end{tabular}

c 
Table 7 Penicillin and ampicillin sensitivities of gonococci grown from patients with subsequent recurrences

\begin{tabular}{|c|c|c|c|c|c|c|c|}
\hline \multirow{3}{*}{ Group } & \multirow{3}{*}{$\begin{array}{l}\text { Time of } \\
\text { recurrence }\end{array}$} & \multicolumn{4}{|c|}{ Sensitivities $(\mu \mathrm{g} / \mathrm{ml})$} & \multirow{3}{*}{ No data } & \multirow{3}{*}{ Total } \\
\hline & & \multicolumn{2}{|c|}{0.06 or less } & \multicolumn{2}{|c|}{0.125 or more } & & \\
\hline & & Ampicillin & Penicillin & Ampicillin & Penicillin & & \\
\hline \multirow[t]{4}{*}{$\mathbf{A}$} & Week & & & & & & \\
\hline & First & 2 & 2 & 0 & 0 & 0 & \\
\hline & Second & 0 & $\overline{0}$ & 0 & 0 & 0 & 8 \\
\hline & $>2$ weeks & 4 & 5 & 2 & 1 & 0 & \\
\hline \multirow[t]{4}{*}{ B } & Week & & & & & & \\
\hline & First & 2 & 2 & 1 & 1 & 0 & \\
\hline & Second & 0 & 0 & 0 & 0 & 0 & 13 \\
\hline & $>2$ weeks & 6 & 7 & 2 & 1 & 2 & \\
\hline
\end{tabular}

The incidence of side effects was small. There were no allergic reactions, mainly because all patients had been questioned carefully about any history of allergy to penicillin.

The number of strains of $N$. gonorrhoeae sensitive to $0 \cdot 125 \mu \mathrm{g} / \mathrm{ml}$ or more of penicillin at The London Hospital in 1968-69 was $19.9 \%$ (164 of 825 strains). This figure had increased to $32.9 \%$ (72 of 228 strains) in 1972 (Rodin and Seth, 1972) and was $30 \%$ (83 of 227 strains) in 1975 (Taylor and Seth, 1975). The current figure of $22 \cdot 2 \%$ (40 of 180 strains) suggests a shift towards more sensitive strains in the last three years. This may be related to the policy of treatment with high doses used in recent years (Olsen and Lomholt, 1969).

We thank Mrs Astrid Forse of the Venereal Disease Reference Laboratory, and Mr S. Goldsmith and the nursing staff for their help in this trial.

\section{Ref erences}

Leigh, D. A., Reeves, D. S., Simmons, K., Thomas, A. L., and Wilkinson, P. J. (1976). Talampicillin: a new derivative of ampicillin. British Medical Journal, 1, 1378-1380.

Olsen, G. A., and Lomholt, G. (1969). Gonorrhoea treated by a combination of probenecid and sodium penicillin G. British Journal of Venereal Diseases, 45, 144-148.

Price, J. D., Fluker, J. L., and Giles, A. J. H. (1977). Oral talampicillin in the treatment of gonorrhoea. British Journal of Venereal Diseases, 53, 113-114.

Rodin, P., and Seth, A. D. (1972). Treatment of gonorrhoea with cotrimoxazole, procaine penicillin alone, and procaine penicillin plus probenecid. British Journal of Venereal Diseases, 48, 517-521.

Taylor, P. K., and Seth. A. D. (1975). Ampicillin plus probenecid compared with procaine penicillin plus probenecid in the treatment of gonorrhoea. British Journal of Venereal Diseases, 51, 183-187.

Willcox, R. R. (1976). Single oral dose of $1.5 \mathrm{~g}$ talampicillin in the treatment of gonorrhoea. British Journal of Venereal Diseases, 52, $184-186$. 